\title{
Spontaneous mediastinal haematoma
}

\author{
Yasuyuki Chida, ${ }^{1}$ Ryota Inokuchi, ${ }^{2}$ Tokiya Ishida, ${ }^{1}$ Kazuaki Shinohara ${ }^{1}$
}

${ }^{1}$ Emergency and Critical Care Medicine, Ohta Nishinouchi Hospital, Koriyama, Japan ${ }^{2}$ Emergency and Critical Care Medicine, The University of Tokyo Hospital, BunkyoKu, Japan

\section{Correspondence to} Dr Ryota Inokuchi, inokuchir-icu@h.u-tokyo.ac.jp

Accepted 18 October 2016

\section{(a) CrossMark}

To cite: Chida $Y$, Inokuchi R, Ishida $T$, et al. BMJ Case Rep Published online: [please include Day Month Year] doi:10.1136/ bcr-2016-217799

\section{DESCRIPTION}

A healthy man aged 32 years, with no notable family or medical history and no history of trauma, reported of sudden severe back pain on stretching and holding his breath while working at his desk. Apart from

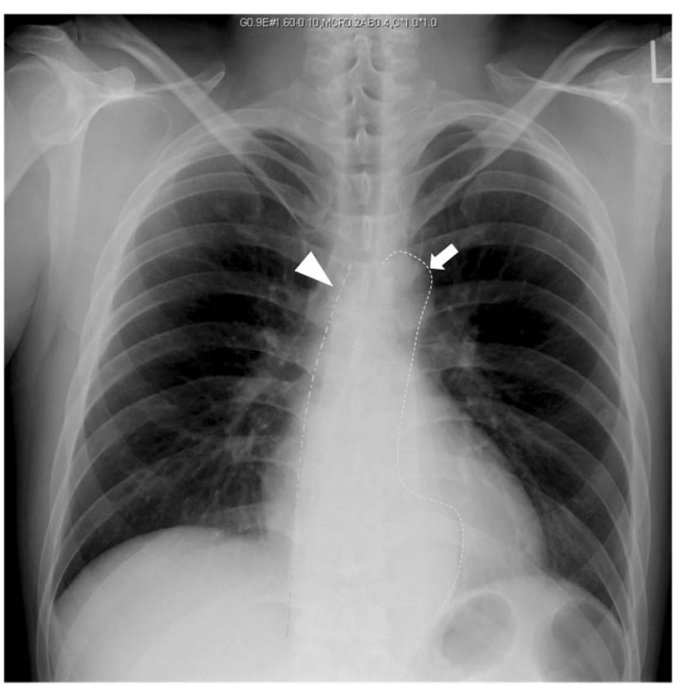

Figure 1 Chest $\mathrm{X}$-ray showed widening of the right paraspinal line (arrowhead) and para-aortic line (arrow).

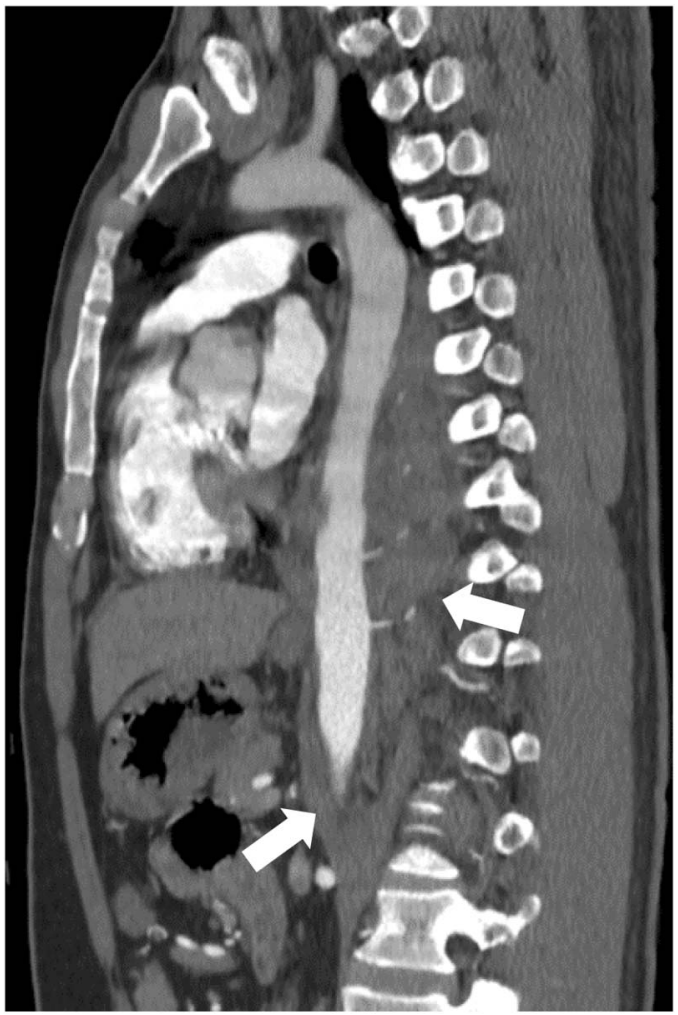

Figure 2 Sagittal contrast-enhanced CT showed the mediastinal haematoma surrounding the descending aorta (arrows). tachypnoea, his vital signs and physical examination were normal. A chest radiograph showed mediastinal widening (figure 1). Results of laboratory tests, including coagulation tests-prothrombin time, activated partial thromboplastin time and erythrocyte sedimentation rate-were all within normal limits. Contrast-enhanced CT revealed a mediastinal haematoma surrounding the descending aorta, with no aortic dissection or extravasation (figure 2). Contrast oesophagography detected no oesophageal rupture. Intercostal artery catheter angiography demonstrated no extravasation or aneurysm. Given his haemodynamic stability, conservative management was initiated. On day 2, repeat CT showed some haematoma absorption. One month postadmission, the haematoma had resolved.

Although rare, a spontaneous mediastinal haematoma may result from mediastinal small-vessel injury following a sudden intrathoracic pressure increase. ${ }^{1}$ It presents with chest pain and dyspnoea. ${ }^{2}$ Determining the bleeding origin is vital. Minimally invasive port-access thoracoscopy can be used in haemodynamically stable, low-risk patients. Alternatively, such patients can be managed conservatively, with serial imaging to assess haematoma resolution. ${ }^{3}$

\section{Learning points}

- Physicians should consider a spontaneous mediastinal haematoma when finding mediastinal widening on chest radiography.

- Determining the bleeding origin is vital.

- In haemodynamically stable in young people with no risk, spontaneous mediastinal haematoma can be managed conservatively, with serial follow-up imaging to assess for resolution.

Contributors $\mathrm{YC}, \mathrm{YI}$ and $\mathrm{KS}$ contributed to patient management. YC drafted the initial manuscript. RI critically reviewed manuscript. All authors contributed to writing the manuscript. All the authors have provided written consent for publication.

Competing interests None declared.

Patient consent Obtained.

Provenance and peer review Not commissioned; externally peer reviewed.

\section{REFERENCES}

1 Tanaka T, Ueda K, Hayashi M, et al. Minimally invasive treatment for spontaneous mediastinal hematoma. Surgery 2009;145:248-9.

2 Katabathina VS, Restrepo CS, Martinez-Jimenez $S$, et al. Nonvascular, nontraumatic mediastinal emergencies in adults: a comprehensive review of imaging findings. Radiographics 2011;31:1141-60.

3 Li X, Liu L, Cao D, et al. Spontaneous hematoma of posterior mediastinum with an uncommon cause: a case report and review of the literature. Clin Pract 2016;6:838. 
Copyright 2016 BMJ Publishing Group. All rights reserved. For permission to reuse any of this content visit http://group.bmj.com/group/rights-licensing/permissions.

BMJ Case Report Fellows may re-use this article for personal use and teaching without any further permission.

Become a Fellow of BMJ Case Reports today and you can:

- Submit as many cases as you like

- Enjoy fast sympathetic peer review and rapid publication of accepted articles

- Access all the published articles

- Re-use any of the published material for personal use and teaching without further permission

For information on Institutional Fellowships contact consortiasales@bmjgroup.com

Visit casereports.bmj.com for more articles like this and to become a Fellow 